\title{
PENGARUH PERSEPSI KEINFORMATIFAN, HARGA, KEGUNAAN, DAN KEMUDAHAN PENGGUNAAN TERHADAP MINAT PEMBELIAN ULANG KONSUMEN GO-FOOD
}

\author{
Elrio Purnomo Hidayat 1 \\ Eristia Lidia Paramita ${ }^{2}$
}

\author{
1,2 Universitas Kristen Satya Wacana, Jawa Tengah, Indonesia \\ email: elriopurnomo@gmail.com ${ }^{1}$, eristia.paramita@uksw.edu ${ }^{2}$
}

\begin{abstract}
ABSTRAK
Pesatnya perkembangan teknologi mengubah perindustrian dunia menjadi semakin futuristik. Dunia industri yang semakin maju menuntut perusahaan untuk berkomitmen dalam upaya memuaskan konsumen. Kepuasan konsumen berperan penting dalam terwujudnya minat pembelian ulang. Studi ini bertujuan untuk mendeskripsikan pengaruh empat faktor persepsi penting terhadap minat beli ulang melalui kepuasan konsumen pada aplikasi Go-Food. Pengumpulan data dilakukan menggunakan kuesioner secara online dengan jumlah sampel sebanyak 200 responden. Teknik analisis yang digunakan adalah Structural Equation Modeling (SEM). Hasil dari penelitian ini menunjukan bahwa persepsi harga dan persepsi kegunaan berpengaruh signifikan terhadap kepuasan konsumen, sedangkan persepsi keinformatifan dan persepsi kemudahan tidak berpengaruh signifikan.

Kata kunci: Persepsi Keinformatifan; Persepsi Harga; TAM; Kepuasan Konsumen; Minat Pembelian Ulang
\end{abstract}

\begin{abstract}
Technology's rapid advancement has transformed the global economy, making it more futuristic. Companies must be dedicated to serving customers in an increasingly advanced industrial environment. The realization of repurchase intention is heavily influenced by consumer satisfaction. This study aims to describe the influence of four important perceptual factors on repurchase intention through consumer satisfaction in the Go-Food application. An online questionnaire was used to collect the data, with a total sample size of 200 respondents. The analysis technique used is Structural Equation Modeling (SEM). According to the results, perceived of price and perceived usefulness have a substantial effect on customer satisfaction, while perceived informativeness and perceived ease of use have no significant impact.

Keywords: Perception of informativeness; Perception of Price; TAM; Consumer Satisfaction; Repurchase Intention
\end{abstract}




\section{PENDAHULUAN}

Kemajuan teknologi yang semakin mutakhir memicu seluruh sektor perindustrian dunia berevolusi secara dramatis menuju ke era yang lebih futuristik (Chen, 2019). Lambat-laun semakin banyak bisnis startup yang hadir dengan user interface yang berbeda sebagai sarana untuk memudahkan aktivitas masyarakat. Kehadiran internet dalam modernisasi menciptakan berbagai macam peluang bisnis yang dapat dieksplorasi oleh para pelaku bisnis. Hasil survei yang dilakukan APJII (2019) pada 2018 menyatakan bahwa $64.8 \%$ dari total populasi penduduk Indonesia sebesar 264.16 juta orang telah terhubung dengan perangkat internet. Dapat diindikasikan bahwa sebesar 171.17 juta penduduk Indonesia merupakan pengguna aktif Internet. Seiring berjalannya waktu, dinamika masyarakat perlahan berubah ke arah serba instan di mana terdapat tuntutan akan kepraktisan dan kecepatan di berbagai situasi dalam bermasyarakat, tidak terkecuali untuk memenuhi berbagai kebutuhan pokok seperti makanan dan minuman (Indraswari \& Kusuma, 2018). Hal ini ditandai dengan masuknya era revolusi industri 4.0 di mana smartphone beserta isinya telah mengubah gaya hidup masyarakat Indonesia pada aspek fundamental karena aksesibilitasnya yang dapat digunakan di manapun dan kapanpun (Hidayatullah et al. 2018).

Data yang dikemukakan oleh BPS Kota Salatiga tahun 2018 menunjukan bahwa jumlah penduduk di Kota Salatiga mencapai 191.571 jiwa di mana terjadi peningkatan pada setiap tahunnya dari tahun 2016 dengan jumlah 186.420 jiwa. Hal inilah yang dimanfaatkan para pelaku bisnis dalam bidang kuliner untuk membangun bisnisnya di tengah masyarakat yang dinamis dalam kesibukan dan aktivitas keseharian dengan berharap akan ada konsep simple mechanism dalam proses pemesanan hingga transaksi sehingga dapat menjaga efektivitas dan efisiensi waktu. Dalam penelitiannya, Hidayatullah et al. (2018) menjelaskan bahwa generasi milenial membutuhkan segala sesuatu harus serba cepat dan detil pada penyampaian informasi kepada end user consumer. Generasi milenial cenderung memiliki karakteristik gaya hidup konsumtif serta smartphone-sektarian yang berarti smartphone tidak dapat dipisahkan dari aktivitas keseharian. Brenda L Curtis et al. (2019) menjelaskan bahwa generasi milenial menggunakan ponsel pintar terutama untuk mengakses internet. Dapat diketahui bahwa generasi milenial menggunakan Go-Food karena terbatasnya waktu untuk menyiapkan kebutuhan makanan di tengah padatnya aktivitas (Muslimin, 2012).

Diketahui bahwa perilaku konsumtif, cenderung malas dan pemanfaatan teknologi oleh generasi milenial berpengaruh positif terhadap keputusan penggunaan aplikasi Go-Food (Hidayatullah et al. 2018). Popularitas akan food delivery dapat dikaitkan dengan banyak manfaat yang ditawarkan (Babu, Sophia, \& Dave, 2020). Go-Food menyediakan segala fitur pendukung seperti nama restaurant, lokasi, daftar menu, harga produk, estimasi ongkos kirim hingga profil kurir tersedia dengan jelas sehingga aplikasi ini dinilai sebagai aplikasi yang customer friendly. Ketersediaan informasi secara mendetil dan lengkap dengan mempertimbangkan pemahaman konsumen memengaruhi kepuasan konsumen (Wardoyo, 2013). Hastuti (2019) mengemukakan bahwa aplikasi Go-Jek telah diunduh oleh masyarakat Indonesia sebanyak 142 juta kali. Ini memperkuat asumsi bahwa masyarakat Indonesia telah percaya terhadap setiap layanan yang ada di 
dalam aplikasi Go-Jek tidak terkecuali Go-Food. Data menunjukan bahwa terdapat lebih dari 2 juta mitra Go-Jek yang siap untuk membantu memudahkan aktivitas masyarakat di Indonesia, sehingga baik pelaku bisnis yang menjadi partner Go-Jek serta end user consumer dapat menjaga efektivitas waktu.

Aditya dan Wardhana (2016) dalam penelitiannya menjelaskan bahwa Technology Acceptance Model (TAM) memiliki dua konstruk penting. Konstruksi pertama diuraikan sebagai Perceived Usefulness (persepsi kegunaan) di mana dengan memakai sistem tertentu maka dapat memaksimalkan usaha dan diterima oleh end user consumer. Konstruk selanjutnya yakni Perceived Ease of Use (persepsi kemudahan penggunaan) di mana kemajuan teknologi dianggap tidak memberatkan konsumen namun mempermudah segala akses. Penelitian yang telah dilakukan oleh (Arnindita Palma \& Lestari Andjarwati, 2016; Hitten \& Susanto, 2019; Wingsati \& Prihandono, 2017) menggunakan variabel kepuasan pelanggan sebagai mediasi terhadap minat pembelian ulang. Hanggono (2015) dalam penelitiannya menyatakan bahwa dua konstruk dalam TAM berperan penting dalam determinasi kepuasan konsumen karena mencakup bagaimana penerimaan dan adaptasi konsumen terhadap teknologi yang terus berkembang yang mendukung lajunya bisnis online. Dengan alasan tersebut, maka peneliti hendak menggabungkan kedua variabel tersebut dengan persepsi harga serta persepsi keinformatifan.

Penelitian ini merupakan modifikasi dari penelitian sebelumnya oleh (Chandra \& Cassandra, 2019) yang mengangkat variabel Perceived Usefulness, Perceived Ease of Use dan Perceived Informativeness, lalu dipadukan dengan penelitian (Hitten \& Susanto, 2019) yang mengangkat variabel Perceived of Price terhadap kepuasan konsumen. Dari sejumlah riset yang diacu membuat peneliti menggunakan kepuasan konsumen sebagai variabel mediasi untuk menjembatani empat variabel utama terhadap minat pembelian ulang. Hal ini dilakukan karena selain variabel kepuasan harga yakni variabel Perceived Usefulness, Perceived Ease of Use dan Persepsi Keinformatifan tidak terdapat kaitan langsung dengan Minat Pembelian Ulang sedangkan ketiganya berpengaruh terhadap kepuasan konsumen di mana kepuasan konsumen memiliki pengaruh terhadap minat pembelian ulang (Yonathan, 2013).

Adapun tujuan dari penelitian ini yakni untuk mendeskripsikan dan memahami pengaruh empat faktor persepsi penting terhadap minat beli ulang melalui kepuasan konsumen pada aplikasi Go-Food. Manfaat yang dapat diperoleh dari penelitian ini antara lain sebagai referensi peneliti lain untuk dapat menguraikan dan memahami pengaruh persepsi keinformatifan, harga, kegunaan, kemudahan penggunaan terhadap minat pembelian ulang melalui kepuasan konsumen aplikasi Go-Food. Manfaat lain dari hasil penelitian ini yaitu dapat menjadi sarana informasi yang berguna bagi perusahaan terkait dalam development aplikasi untuk melihat peluang, melakukan evaluasi, dan menetapkan strategi yang tepat melalui ke empat persepsi konsumen yang dibahas untuk mengoptimalkan aset yang dimiliki untuk kemajuan usaha.

Persepsi keinformatifan merupakan persepsi konsumen secara keseluruhan yang meliputi konsistensi, kelengkapan, akurasi dan seberapa memadai sebuah informasi yang diberikan dengan apa yang diterima konsumen (Ruiz-Mafe et al. 
2018). Persepsi keinformatifan juga diartikan sebagai pengukuran seberapa komunikatif suatu informasi dapat berhasil sampai ke konsumen (Webster et al. 2018). Keinformatifan dapat meningkatkan pengetahuan dan pemahaman serta memuaskan kebutuhan kognitif konsumen akan informasi produk atau layanan yang diberikan. Kualitas informasi telah terbukti berdampak besar terhadap estimasi jumlah konsumen yang berpengaruh nyata pada kepercayaan konsumen terhadap suatu perusahaan (Sigurdsson et al. 2018). Informasi juga didefinisikan sebagai suatu instrumen yang dapat membantu konsumen memahami suatu produk yang bersifat persuasif sehingga konsumen dapat dengan mudah menggunakan produk tersebut (Hendraningtiyas \& Soediono, 2015). Persepsi keinformatifan juga diartikan sebagai persepsi konsumen mengenai kualitas informasi yang diterima (Ta'arufi \& Yamit, 2017). Putri (2016) menjelaskan bahwa terdapat dua pendekatan agar informasi dapat sampai ke konsumen dengan baik. Pendekatan tersebut antara lain pendekatan rasional yang berisi ide atau gagasan kelengkapan informasi serta pendekatan emosional yang berupa aspek afektif, kognitif, dan konatif. Informasi akan bersifat persuasif apabila terdapat simbol-simbol pesan, visualisasi, penggunaan jenis huruf, background, hingga tagline yang menarik dari tema tertentu (Ramadhon \& Fardiyan, 2016).

Harga adalah satu-satunya komponen dari marketing yang dapat menghasilkan pendapatan dan fleksibel sehingga dapat diubah dengan cepat (Sepang \& Joel, 2014). Sejatinya harga merupakan jumlah nominal uang yang harus dibayarkan konsumen untuk memperoleh produk dari produsen. Harga dinilai sebagai salah satu penentu keberhasilan produsen karena menjadi penentu seberapa besar profit yang dihasilkan dalam suatu perusahaan (Aristo, 2016). Harga juga didefinisikan sebagai sejumlah uang yang ditagihkan kepada konsumen sebagai imbalan atas produk atau jasa yang diterima oleh konsumen (Swastha, 2016). Pendapat lain yang dikemukakan (Imam Heryanto, 2015) menyatakan bahwa harga merupakan unsur dari pemasaran yang bersifat menghasilkan atau mencetak pendapatan. Rahman (2013) menjelaskan bahwa harga merupakan serangkaian tingkat harga yang dikeluarkan oleh konsumen untuk memperoleh manfaat tertentu yang didapatkan dari suatu produk yang dikonsumsi. Sedangkan persepsi harga sendiri didefinisikan sebagai pandangan konsumen mengenai tinggi, rendah dan kewajaran harga yang berpengaruh kuat dengan kepuasan pembelian (Harjati \& Venesia, 2015). Saat memilih produk, konsumen akan mempertimbangkan persepsi harga (Ayuningrum, 2016). Menurut Sumaedi et al. (2011), perceived of price (persepsi harga) diartikan sebagai evaluasi konsumen akan apa yang dikorbankan dengan apa yang didapatkan. Persepsi harga juga didefinisikan sebagai proses seleksi dan organisir stimulus informasi agar menjadi suatu gambaran produk (Soliha, 2019).

Persepsi kegunaan merupakan salah satu komponen dari Technology Acceptance Model (TAM) yang diartikan sebagai sejauh mana seseorang percaya bahwa penggunaan suatu sistem tertentu dapat meningkatkan kinerja kerjanya (Kucukusta et al. 2015). Dapat diartikan juga dengan menggunakan sistem tertentu, end user consumer dapat menerima dan memaksimalkan kinerjanya (Aditya \& Wardhana, 2016). Dapat diketahui bahwa persepsi kegunaan merupakan suatu manfaat yang dapat dirasakan oleh konsumen yang dijadikan pertimbangan 
seberapa yakin konsumen melakukan transaksi secara online (G. F. C. Putri \& Novianti, 2016). Selain itu, persepsi kegunaan dapat memberikan rasa percaya kepada konsumen bahwa dengan menggunakan teknologi, maka seluruh kinerja akan meningkat (Wardhana, 2019). Amita (2015) menjelaskan bahwa persepsi kegunaan ditafsirkan sebagai suatu kepercayaan mengenai proses decision making di mana apabila konsumen percaya bahwa sistem informasi berguna, maka konsumen akan menggunakannya, begitu juga sebaliknya. Persepsi ini memengaruhi bagaimana konsumen menggunakan sebuah sistem informasi (Wardhana, 2019). Syaninditha \& Setiawan (2017) mengatakan bahwa persepsi kegunaan digunakan untuk memprediksi bagaimana penerimaan konsumen dalam menggunakan sistem informasi. Persepsi kegunaan juga diuraikan sebagai tingkatan seberapa tinggi konsumen mempercayai suatu sistem di mana sistem tersebut dapat memudahkan aktivitas konsumen (Widodo \& Putri, 2017).

Persepsi kemudahan penggunaan dapat didefinisikan sebagai salah satu model TAM sebagai upaya adaptasi konsumen terhadap teknologi yang ditafsirkan sebagai kepercayaan konsumen bahwa teknologi dapat menjauhkan konsumen dari effort. Apabila sebuah sistem dinilai cukup mudah digunakan, konsumen akan cenderung bersedia untuk mempelajari fitur yang ada di dalamnya (Hamid et al. 2016). Perceived Ease of Use juga diartikan sebagai sebuah derajat di mana suatu individu percaya akan digunakannya sebuah teknologi dapat membuat individu tersebut dapat bebas dari upaya atau pekerjaan yang berlebih (Anggraeni, 2015). Menurut (Hamid, 2017) persepsi kemudahan penggunaan merupakan tingkat di mana individu memiliki suatu keyakinan bahwa teknologi informasi adalah tentang segala kemudahan yang dapat diperoleh tanpa membutuhkan upaya yang berlebihan dalam menjalankannya. Pernyataan ini diperkuat oleh penelitian (Syaninditha \& Setiawan, 2017) yang mengatakan bahwa persepsi kemudahan ialah pengukuran seberapa besar tingkat konsumen percaya bahwa hadirnya teknologi sangat mudah dipahami.

Kepuasan konsumen merupakan suatu upaya produsen untuk mempertahankan tingkat konsumen akan produknya (Rahman, 2013). Kepuasan konsumen didefinisikan sejauh mana kinerja suatu produk dapat dibandingkan dengan apa yang diharapkan oleh konsumen (Soliha, 2019). Kepuasan konsumen dapat diartikan juga sebagai perasaan konsumen yang timbul setelah melakukan perbandingan hasil kinerja produk yang dipikirkan terhadap hasil kinerja yang diharapkan. Kepuasan konsumen juga didefinisikan sebagai reaksi atau respon konsumen akan hasil kinerja yang telah dirasakan setelah penggunaan barang atau jasa (Roring et al. 2015). Apabila berkaitan dengan teknologi dan pemanfaatan sistem informasi, kepuasan konsumen dapat diukur melalui Technology Acceptance Model (TAM) (Sidharta \& Boy Suzanto, 2015). Kepuasan konsumen bersifat berkelanjutan di mana apabila setelah pembelian konsumen merasa puas, maka konsumen akan melakukan pembelian kembali (Setiarsih, 2017). Setyo (2017) menjelaskan bahwa puas atau tidaknya konsumen merupakan suatu ungkapan perasaan yang dapat membandingkan hasil kinerja dari barang atau jasa yang diperkirakan dengan hasil kinerja barang atau jasa yang sesungguhnya (aktual). Terdapat tiga tingkatan dalam kepuasan konsumen, beberapa diantaranya yaitu hasil di luar harapan, hasil sesuai harapan dan hasil melebihi dari yang diharapkan 
(Andhini, 2017). Kepuasan konsumen juga didefinisikan sebagai konsep luas yang dipengaruhi berbagai faktor seperti harga, kualitas layanan dan kualitas produk (C. V. Wijaya, 2017). Dapat disimpulkan bahwa kepuasan konsumen merupakan upaya produsen untuk memenuhi suatu kebutuhan yang diharapkan konsumen (W. Wijaya, 2017).

Minat pembelian ulang merepresentasikan apakah end user consumer akan menggunakan atau mengonsumsi sebuah produk berupa barang atau jasa dengan merek, perusahaan atau label yang sama untuk masa mendatang atau tidak (Arnindita Palma \& Lestari Andjarwati, 2016). Menurut (E. K. Kartika, 2014) minat beli ulang merupakan keputusan konsumen secara langsung berdasarkan frekuensi pengalaman yang mengeluarkan biaya dalam rangka memperoleh produk (barang atau jasa). Setiarsih (2017) menjelaskan bahwa minat beli ulang berkaitan erat dengan kepuasan konsumen di mana keputusan pembelian ulang akan dilakukan apabila konsumen puas dengan apa yang diterimanya. Rizky Iryanita (2013) mengatakan bahwa untuk menggencarkan minat beli ulang konsumen, produsen harus memperhatikan segala aspek termasuk kualitas produk yang ditawarkan kepada end user consumer. Minat pembelian ulang ditafsirkan sebagai suatu tahap bagaimana responden atau konsumen bertindak setelah konsumen merasakan suatu kepuasan (Savitri \& Wardana, 2018). Dapat dinyatakan bahwa hasil pengalaman belanja produk dari suatu produsen memengaruhi pembelian selanjutnya (Faradisa et al. 2016).

Hendraningtiyas \& Soediono (2015); (Firmanto \& Rozi, 2018); (Ta'arufi \& Yamit, 2017) menyebutkan bahwa terdapat pengaruh antara persepsi keinformatifan dengan kepuasan konsumen. Chandra \& Cassandra (2019) dalam penelitiannya menyampaikan bahwa apabila dikaitkan dengan obyek yang dibahas yakni aplikasi Go-Food, kelengkapan dan seberapa presisi informasi menciptakan nilai kesesuaian konsumen. Tingkat kepuasan konsumen didukung oleh seberapa tinggi persepsi keinformatifan yang diterima oleh konsumen. Kelengkapan informasi mengenai harga, rincian produk hingga tampilan sistem dan kemudahan untuk digunakan dapat menciptakan suatu kepuasan tertentu dalam menggunakan suatu aplikasi. Dengan demikian, disimpulkan hipotesis pertama adalah:

$\mathrm{H}_{1}$ : Perceived Informativeness Berpengaruh Terhadap Kepuasan Konsumen

Malik et al. (2012) mengatakan bahwa persepsi harga merupakan penafsiran konsumen yang memuat nilai harga serta atribut barang atau jasa yang dikehendaki. Konsumen yang bersedia membayar harga tinggi untuk sebuah barang atau jasa cenderung "sadar merek" dan juga peka terhadap prestige. Harga dinilai dapat memengaruhi pembelian karena dapat membuat pelanggan melakukan penilaian secara emosional dalam komparasi harga yang ditawarkan perusahaan satu dengan yang lain (Rizky Iryanita, 2013). Adinugraha \& H Michael (2014); (Liang et al. 2018); (Pardede \& Haryadi, 2017); (Sumaedi et al. 2011) menjelaskan bahwa persepsi harga memiliki pengaruh terhadap kepuasan konsumen. Dengan demikian, penetapan harga yang tinggi dapat membentuk persepsi konsumen terhadap produk tersebut sangat berkualitas, sebaliknya apabila ditetapkan strategi harga rendah, maka konsumen cenderung mempersepsikan produk tersebut berkualitas rendah (Dwihapsari, 2017). Pardede \& Haryadi (2017) menyatakan bahwa persepsi harga merupakan sebuah nilai yang diberikan konsumen akan suatu produk dalam bentuk 
barang atau jasa yang bersifat subyektif. Sifat persepsi harga yang subyektif juga diperkuat dalam penelitian (Adinugraha \& H Michael, 2014) yang mengatakan bahwa anggapan tinggi, rendah, dan normalnya harga pada masing-masing konsumen tidaklah sama. Pernyataan lain mengartikan persepsi harga sebagai suatu proses seleksi dan interpretasi stimuli dalam suatu rentang harga tertentu (Dwihapsari, 2017). Sekarang ini konsumen cenderung memilih berbelanja online karena persepsi berbelanja yang memiliki tawaran harga yang bervariatif (Ayuningrum, 2016). Dapat disimpulkan bahwa hipotesis ke dua dari penelitian ini adalah:

\section{$\mathrm{H}_{2}$ : Perceived of Price Berpengaruh Terhadap Kepuasan Konsumen}

Hitten \& Susanto (2019); (Umamah \& Pribadi, 2006) mengatakan bahwa Perceived Usefulness (persepsi kegunaan) memengaruhi kepuasan konsumen yang dinyatakan dengan semakin tinggi manfaat yang diberikan dari sebuah aplikasi maka semakin tinggi pula kepuasan konsumen yang diterima. Anggraeni (2015) memaparkan persepsi kegunaan sebagai sebuah pengukuran di mana dalam menggunakan suatu teknologi akan meningkatkan kinerja pada suatu individu. Persepsi kegunaan juga diartikan sebagai suatu kepercayaan akan proses decision making di mana seseorang akan memiliki kepercayaan bahwa sistem informasi yang digunakan sangat berguna untuk kinerjanya (Hamid, 2017). Apabila persepsi kegunaan yang diterima konsumen meningkat, maka akan meningkatkan kepuasan pelanggan di mana akan timbul kecenderungan untuk melakukan pembelian kembali (G. F. C. Putri \& Novianti, 2016). Bila dikaitkan dengan aplikasi Go-Food, kemajuan teknologi akan benar-benar digunakan masyarakat apabila memiliki fungsi dan guna yang jelas sehingga dalam penelitian ini, Go-Food memiliki fungsi dan kegunaan yang memudahkan masyarakat dalam beraktivitas sehingga diperhitungkan sebagai teknologi yang berhasil (Nur, 2019). Berdasarkan uraian tersebut, dapat dinyatakan bahwa hipotesis ke tiga dalam penelitian ini adalah:

$\mathrm{H}_{3}$ : Perceived Usefulness Berpengaruh Terhadap Kepuasan Konsumen

Kemudahan mekanisme dalam menjalankan sebuah aplikasi dengan intensitas tertentu dapat menunjukan apakah konsumen mempercayai aplikasi yang digunakan dapat mempermudah aktivitasnya atau tidak (Natalia et al. 2019). Sama seperti Perceived Usefulness di mana keduanya merupakan dua konstruksi utama dalam TAM, persepsi kemudahan juga memiliki pengaruh terhadap kepuasan konsumen (Hitten \& Susanto, 2019). Dalam penelitian (G. F. C. Putri \& Novianti, 2016) disampaikan bahwa persepsi kemudahan ini berlandaskan sejauh mana seorang konsumen dapat merasakan bagaimana mudahnya menjalankan dan berinteraksi dengan teknologi. Aspek ini ditekankan pada aplikasi Go-Food dalam memberikan kemudahan aksesibilitas, menu user-interface hingga tersedianya Langkah-langkah pemakaian (Wardoyo, 2013). Kemudahan dalam menggunakan suatu aplikasi sangat memengaruhi kepuasan seseorang akan kinerja aplikasi tersebut. Go-Food di dalam Go-Jek selalu memberikan update besar pada aplikasinya sehingga user interface maupun kinerja akurasi aplikasi dapat selalu dioptimalkan. Dengan demikian, peneliti menyatakan bahwa hipotesis yang ke empat yaitu:

$\mathrm{H}_{4}$ : Perceived Ease of Use Berpengaruh Terhadap Kepuasan Konsumen 
Kepuasan konsumen sangat bergantung pada bagaimana hasil atau kinerja produk dapat memberikan nilai relatif terhadap apa yang menjadi ekspektasi konsumen (C. V. Wijaya, 2017). Menurut (Yonathan, 2013) kepuasan konsumen disebut sebagai sikap konsumen secara menyeluruh setelah menggunakan produk berupa barang dan jasa. Apabila dikaitkan dengan obyek penelitian secara riil, kepuasan konsumen dapat diukur dengan tiga indikator yakni fulfillment, pleasure, dan ambivalence (Adinugraha \& H Michael, 2014). Kepuasan konsumen akan mendukung penuh minat pembelian ulang apabila tingkat kepuasan yang diterima konsumen telah sesuai dengan ekspektasi konsumen bahkan dapat melebihi apa yang diharapkan konsumen. Dengan ini, hipotesis ke lima adalah:

$\mathrm{H}_{5}$ : Kepuasan Konsumen Berpengaruh Terhadap Minat Pembelian Ulang

\section{MODEL PENELITIAN}

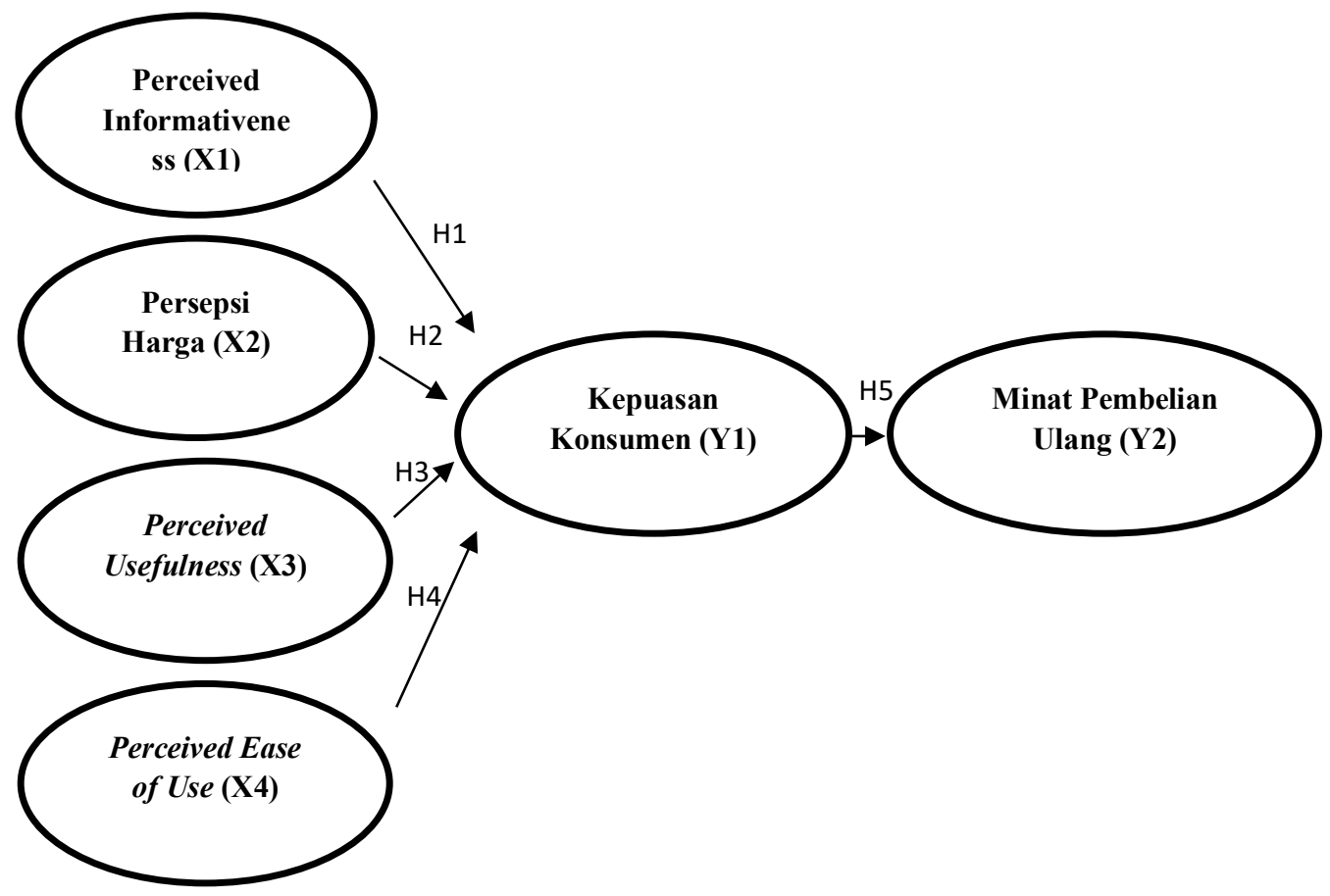

\section{Gambar 1. Model Penelitian}

Sumber: Modifikasi (Chandra \& Cassandra, 2019; Hitten \& Susanto, 2019)

\section{METODE PENELITIAN}

Penelitian ini merupakan penelitian dengan metode kuantitatif Penelitian kuantitatif bertujuan untuk mengetahui adanya keterkaitan antar dua variabel atau lebih. Kajian ini merupakan explanatory research yang digunakan untuk melakukan analisis adanya hubungan antar satu variabel dengan variabel lain atau dengan cara apa variabel dapat memengaruhi variabel lainnya dalam uji hipotesis (Hitten \& Susanto, 2019). Dalam pendekatan penelitian ini, peneliti hendak mengukur bagaimana faktor persepsi dapat memengaruhi minat pembelian ulang yang dimediasi dengan kepuasan konsumen. 
Dalam penelitian ini, jenis data primer digunakan untuk diolah dan dianalisis. Data diperoleh secara langsung melalui jawaban kuesioner dari responden yang disebarluaskan melalui piranti Google Form pada masyarakat yang menggunakan jasa Go-Food sebagai aplikasi pilihan pesan antar makanan.

Penelitian ini menggunakan unit analisis yang diteliti yakni masyarakat di Jawa Tengah dengan total 34.940.078 penduduk sebagai populasi (BPS, 2020). Peneliti menggunakan cakupan wilayah Jawa Tengah pasalnya mudah dijangkau bagi peneliti serta tingginya tingkat konsumsi rumah tangga (Household consumption expenditure) berupa makanan dan minuman di Jawa Tengah (BPS, 2020). Adapula teknik pengambilan sampel yang digunakan yakni purposive sampling dengan beberapa karakteristik yang wajib dimiliki responden yang ditimbang untuk memenuhi ekspektasi peneliti. Syarat yang harus dipenuhi adalah: (1) Merupakan konsumen Go-Food yang bertempat tinggal di Jawa Tengah; (2) Berusia 17 tahun ke atas dengan asumsi sudah memiliki penghasilan atau mendapatkan uang saku secara rutin; (3) Telah melakukan pembelian baik makanan dan minuman pada aplikasi Go-Food. Mengingat tingkat kepercayaan yang harus mencapai 95\% $(a=0.05)$ dan semakin besarnya sampel yang mendekati populasi akan memperkecil tingkat kesalahan, maka sampel yang digunakan dalam penelitian ini berjumlah sebanyak 200 responden. Dalam melakukan perhitungan dari masing-masing variabel, peneliti menggunakan skala penelitian dengan mengukur sikap dan opini dari responden yang disebut sebagai Likert scale.

Pada saat seluruh data primer dari hasil penyebarluasan kuesioner diperoleh, data akan diolah dan dianalisa menggunakan teknik analisis data Structural Equation Model (SEM). Teknik analisis SEM adalah penggabungan dari dua metode yang terpisah yakni model persamaan simultan yang dikembangkan di Ekonometrik serta analisis faktor yang dikembangkan di ilmu psikologi dan psikometri Terdapat dua pendekatan SEM antara lain SEM berbasis Covariance dan Variancel Component (Ghozali, 2017). Tujuan dari teknik analisis ini yaitu dapat menyelesaikan model bertingkat secara bersamaan yang tidak dapat diselesaikan oleh persamaan regresi linear.

\section{HASIL DAN PEMBAHASAN}

Sebelumnya, dilakukan uji pre-test untuk mengukur validitas dan reliabilitas sampel responden. Variabel Persepsi Keinformatifan, Persepsi Harga, Persepsi Kegunaan, Persepsi Kemudahan Penggunaan, Kepuasan Konsumen, dan Minat Pembelian Ulang dinyatakan lolos uji validitas dari hasil pre-test dengan responden sebanyak 30 partisipan. Data dinyatakan valid apabila jumlah $r$ hitung $>r$ tabel. Ketentuan $r$ tabel untuk 30 responden dengan tingkat signifikansi 0,05 yakni 0,3494. Uji reliabilitas pada pre-test penelitian ini juga melibatkan 30 responden. Setiap butir pertanyaan akan dinyatakan reliabel atau konsisten apabila nilai Cronbach's Alpha $>0,6$. Data yang sudah terkumpul kemudian diolah untuk mengidentifikasi jenis kelamin, usia, pekerjaan, lama penggunaan aplikasi, penggunaan aplikasi dalam 3 bulan terakhir, hingga rata-rata nominal yang dikeluarkan. Karakteristik responden dijelaskan dengan analisa deskriptif. Analisis deskriptif merupakan wujud analisa data penelitian guna melakukan pengujian yang bersifat generalisasi dari hasil penelitian (Nasution, 2017). 
Tabel 1.

Karakteristik Responden

\begin{tabular}{|c|c|c|c|c|c|}
\hline Characteristics & Categories & Frequency & Percent & $\begin{array}{c}\text { Valid } \\
\text { Percent }\end{array}$ & $\begin{array}{c}\text { Cumulative } \\
\text { Percent }\end{array}$ \\
\hline \multirow{3}{*}{ Jenis Kelamin } & Laki-laki & 88 & 44 & 44 & 44 \\
\hline & Perempuan & 112 & 56 & 56 & 100 \\
\hline & Total & 200 & 100 & 100 & \\
\hline \multirow{6}{*}{ Usia } & 17-20 tahun & 60 & 30 & 30 & 30 \\
\hline & $21-30$ tahun & 127 & 63.5 & 63.5 & 93.5 \\
\hline & $31-40$ tahun & 5 & 2.5 & 2.5 & 96 \\
\hline & 41-45 tahun & 4 & 2 & 2 & 98 \\
\hline & $>45$ tahun & 4 & 2 & 2 & 100 \\
\hline & Total & 200 & 100 & 100 & \\
\hline \multirow{5}{*}{ Pekerjaan } & Pelajar/Mahasiswa & 164 & 82 & 82 & 82 \\
\hline & $\begin{array}{l}\text { Ibu Rumah } \\
\text { Tangga }\end{array}$ & 8 & 4 & 4 & 86 \\
\hline & Wirausaha & 10 & 5 & 5 & 91 \\
\hline & $\begin{array}{c}\text { Pegawai } \\
\text { Negeri/Swasta }\end{array}$ & 18 & 9 & 9 & 100 \\
\hline & Total & 200 & 100 & 100 & \\
\hline \multirow{6}{*}{$\begin{array}{c}\text { Lama } \\
\text { Penggunaan }\end{array}$} & $<1$ tahun & 24 & 12 & 12 & 12 \\
\hline & $<2$ tahun & 43 & 21.5 & 21.5 & 33.5 \\
\hline & $<3$ tahun & 71 & 35.5 & 35.5 & 69 \\
\hline & $<4$ tahun & 44 & 22 & 22 & 91 \\
\hline & $>5$ tahun & 18 & 9 & 9 & 100 \\
\hline & Total & 200 & 100 & 100 & \\
\hline \multirow{4}{*}{$\begin{array}{c}\text { Frekuensi } 3 \\
\text { Bulan Terakhir }\end{array}$} & $<2$ kali & 68 & 34 & 34 & 34 \\
\hline & $<4$ kali & 65 & 32.5 & 32.5 & 66.5 \\
\hline & $>6$ kali & 67 & 33.5 & 33.5 & 100 \\
\hline & Total & 200 & 100 & 100 & \\
\hline \multirow[t]{2}{*}{ Lanjutan Tabel 1.} & $<\operatorname{Rp} 15.000,-$ & 15 & 7.5 & 7.5 & 7.5 \\
\hline & $<\operatorname{Rp} 30.000,-$ & 65 & 32.5 & 32.5 & 40 \\
\hline $\begin{array}{l}\text { Nominal yang } \\
\text { Dikeluarkan }\end{array}$ & $<\operatorname{Rp} 45.000,-$ & 76 & 38 & 38 & 78 \\
\hline \multirow[t]{2}{*}{ Bersambung... } & $>\operatorname{Rp} 60.000,-$ & 44 & 22 & 22 & 100 \\
\hline & Total & 200 & 100 & 100 & \\
\hline
\end{tabular}

Sumber: Data primer yang diolah (2021) 
Menurut karakteristik jenis kelamin dari hasil olah data dalam Tabel 1, dapat diketahui bahwa dari total responden sebanyak 200, terdapat 88 laki-laki atau $44 \%$ dan 112 perempuan atau 56\%. Dalam penelitian ini responden didominasi oleh responden berjenis kelamin wanita. Berdasarkan karakteristik usia dalam penelitian ini didominasi responden berusia antara 21-30 tahun sebanyak 63.5\%. Menurut karakteristik pekerjaan sebagian besar responden adalah pelajar/mahasiswa dengan frekuensi 164 responden. Berdasarkan karakteristik lama penggunaan, sebagian responden lama memakai layanan Go-Food yaitu selama kurang dari 3 tahun dengan prosentase $35.5 \%$. Menurut frekuensi pembelian 3 bulan terakhir sebagian besar responden yang melakukan pembelian melalui layanan Go-Food yaitu kurang 2 kali. Berdasarkan nominal yang dikeluarkan mayoritas responden melakukan pembelian dengan nominal kurang dari Rp 45.000 dengan jumlah 76 responden.

Peneliti menggunakan analisis model persamaan struktural atau SEM (Structural Equation Model) sebagai sarana pengolahan data. Byrne (1998) menjelaskan bahwa secara umum analisis SEM dibedakan menjadi dua bagian, yakni model pengukuran dan model persamaan struktural. Analisis SEM didefinisikan sebagai salah satu metode statistik dalam melakukan analisis multivariate yang dapat digunakan untuk pendekatan confirmatory dari teori struktural yang terjadi.

Tabel 2.

Uji Validitas

\begin{tabular}{|c|c|c|c|c|c|c|c|}
\hline \multicolumn{3}{|c|}{ Standardized Regression Weight } & \multirow{2}{*}{$\begin{array}{c}\text { Estimate } \\
0.783\end{array}$} & \multicolumn{3}{|c|}{ Standardized Regression Weight } & \multirow{2}{*}{$\begin{array}{c}\text { Estimate } \\
0.674\end{array}$} \\
\hline HRG1 & $\begin{array}{l}<- \\
--\end{array}$ & HRG & & PEU1 & $\begin{array}{l}<- \\
--\end{array}$ & PEU & \\
\hline HRG2 & $\begin{array}{l}<- \\
--\end{array}$ & HRG & 0.698 & PEU2 & $\begin{array}{l}<- \\
--\end{array}$ & PEU & 0.717 \\
\hline HRG3 & $\begin{array}{l}<- \\
--\end{array}$ & HRG & 0.735 & PEU3 & $\begin{array}{l}<- \\
--\end{array}$ & PEU & 0.79 \\
\hline HRG4 & $\begin{array}{l}<- \\
--\end{array}$ & HRG & 0.543 & PEU4 & $\begin{array}{l}<- \\
--\end{array}$ & PEU & 0.78 \\
\hline HRG5 & $\begin{array}{l}<- \\
--\end{array}$ & HRG & 0.672 & PEU5 & $\begin{array}{l}<- \\
--\end{array}$ & PEU & 0.76 \\
\hline HRG6 & $\begin{array}{l}<- \\
--\end{array}$ & HRG & 0.546 & PEU6 & $\begin{array}{l}<- \\
--\end{array}$ & PEU & 0.563 \\
\hline HRG7 & $\begin{array}{l}<- \\
--\end{array}$ & HRG & 0.778 & PEU7 & $\begin{array}{l}<- \\
--\end{array}$ & PEU & 0.643 \\
\hline PUS1 & $\begin{array}{l}<- \\
--\end{array}$ & PUS & 0.71 & KEP1 & $\begin{array}{l}<- \\
--\end{array}$ & KEP & 0.767 \\
\hline PUS2 & $\begin{array}{l}<- \\
--\end{array}$ & PUS & 0.707 & KEP2 & $\begin{array}{l}<- \\
--\end{array}$ & KEP & 0.774 \\
\hline PUS3 & $\begin{array}{l}<- \\
--\end{array}$ & PUS & 0.705 & KEP3 & $\begin{array}{l}<- \\
--\end{array}$ & KEP & 0.688 \\
\hline PUS4 & $\begin{array}{l}<- \\
--\end{array}$ & PUS & 0.709 & KEP4 & $\begin{array}{l}<- \\
--\end{array}$ & KEP & 0.764 \\
\hline PUS5 & $<-$ & PUS & 0.633 & KEP5 & $<-$ & KEP & 0.64 \\
\hline
\end{tabular}


Lanjutan Tabel 2.

\begin{tabular}{|c|c|c|c|c|c|c|c|}
\hline \multicolumn{3}{|c|}{ Standardized Regression Weight } & \multirow{2}{*}{$\begin{array}{c}\text { Estimate } \\
0.67\end{array}$} & \multicolumn{3}{|c|}{ Standardized Regression Weight } & \multirow{2}{*}{$\begin{array}{c}\text { Estimate } \\
0.798\end{array}$} \\
\hline PUS6 & $\begin{array}{l}<- \\
--\end{array}$ & PUS & & KEP6 & $\begin{array}{l}<- \\
--\end{array}$ & KEP & \\
\hline PUS7 & $\begin{array}{l}<- \\
--\end{array}$ & PUS & 0.716 & KEP7 & $<-$ & KEP & 0.783 \\
\hline INF1 & $\begin{array}{l}<- \\
--\end{array}$ & INF & 0.706 & MIN1 & $\begin{array}{l}<- \\
--\end{array}$ & MIN & 0.74 \\
\hline INF2 & $\begin{array}{l}<- \\
--\end{array}$ & INF & 0.543 & MIN2 & $\begin{array}{l}<- \\
--\end{array}$ & MIN & 0.73 \\
\hline INF3 & $\begin{array}{l}<- \\
--\end{array}$ & INF & 0.533 & MIN3 & $\begin{array}{l}<- \\
--\end{array}$ & MIN & 0.804 \\
\hline INF4 & $\begin{array}{l}<- \\
--\end{array}$ & INF & 0.555 & MIN4 & $\begin{array}{l}<- \\
--\end{array}$ & MIN & 0.744 \\
\hline INF5 & $\begin{array}{l}<- \\
--\end{array}$ & INF & 0.721 & MIN5 & $\begin{array}{l}<- \\
--\end{array}$ & MIN & 0.755 \\
\hline INF6 & $\begin{array}{l}<- \\
--\end{array}$ & INF & 0.541 & MIN6 & $\begin{array}{l}<- \\
--\end{array}$ & MIN & 0.765 \\
\hline INF7 & $\begin{array}{l}<- \\
--\end{array}$ & INF & 0.701 & & & & \\
\hline
\end{tabular}

Sumber: Data primer yang diolah (2021)

Pengujian ini digunakan untuk mengukur apakah kuesioner yang disebarluaskan tersebut valid atau tidak. Uji validitas juga digunakan untuk mengukur bagaimana hubungan variabel laten dengan masing-masing indikatornya. Sebuah indikator dapat dikatakan valid apabila value dari Standardized Regression Weight dari masing-masing variabel laten berjumlah $>$ 0,5. Berdasarkan Tabel 2, diperoleh nilai Standardized Regression Weight masingmasing indikator terhadap variabel laten. Dengan kriteria nilai value $>0.5$ maka dapat disimpulkan semua indikator dalam penelitian ini dinyatakan valid.

Tabel 3.

Uji Reliabilitas

\begin{tabular}{lcc}
\hline Variable & Cronbach's Alpha & Keterangan \\
\hline INF & 0.802 & Reliabel \\
HRG & 0.777 & Reliabel \\
PUS & 0.864 & Reliabel \\
PEU & 0.867 & Reliabel \\
KEP & 0.853 & Reliabel \\
MIN & 0.886 & Reliabel \\
\hline \multicolumn{2}{l}{ Sumber: }
\end{tabular}

Sumber: Data primer yang diolah (2021)

Pengujian reliabilitas dilakukan untuk menghitung besarnya reliability model yang memaparkan adanya banyaknya indikator yang memiliki kesesuaian derajat dengan baik. Uji reliabilitas diukur dengan perhitungan nilai c.r. $>0,60$. Melalui Tabel 3, diperoleh masing-masing nilai Cronbach's Alpha dengan kriteria nilai c,r, $>$ 0.6. Dengan demikian dapat dinyatakan bahwa seluruh variabel laten dalam penelitian ini konsisten/ reliabel dan layak digunakan untuk diolah ke tahap uji berikutnya. 
Tabel 4.

Uji Normalitas

\begin{tabular}{|c|c|c|c|c|c|c|}
\hline Variable & $\min$ & $\max$ & skew & c.r. & kurtosis & c.r. \\
\hline MIN6 & 1 & 5 & -0.876 & -5.058 & 0.623 & 1.798 \\
\hline MIN5 & 1 & 5 & -0.434 & -2.504 & -0.329 & -0.95 \\
\hline MIN4 & 1 & 5 & -0.411 & -2.372 & -0.515 & -1.486 \\
\hline MIN3 & 1 & 5 & -1 & -5.774 & 0.752 & 2.17 \\
\hline MIN2 & 2 & 5 & -1.021 & -5.894 & 0.59 & 1.704 \\
\hline MIN1 & 1 & 5 & -1.309 & -7.555 & 2.364 & 6.824 \\
\hline KEP7 & 1 & 5 & -0.655 & -3.779 & -0.471 & -1.359 \\
\hline KEP6 & 2 & 5 & -0.838 & -4.841 & 0.156 & 0.451 \\
\hline KEP5 & 1 & 5 & -0.433 & -2.499 & -0.613 & -1.769 \\
\hline KEP4 & 3 & 5 & -0.603 & -3.481 & -0.774 & -2.234 \\
\hline KEP3 & 2 & 5 & -0.488 & -2.815 & -0.624 & -1.8 \\
\hline KEP2 & 2 & 5 & -0.803 & -4.636 & 0.19 & 0.549 \\
\hline KEP1 & 2 & 5 & -0.79 & -4.563 & -0.089 & -0.257 \\
\hline PEU7 & 2 & 5 & -1.142 & -6.595 & 0.622 & 1.794 \\
\hline PEU6 & 2 & 5 & -0.748 & -4.318 & -0.336 & -0.969 \\
\hline PEU5 & 2 & 5 & -0.771 & -4.451 & -0.192 & -0.554 \\
\hline PEU4 & 2 & 5 & -1.039 & -6.001 & 0.278 & 0.802 \\
\hline PEU3 & 3 & 5 & -0.871 & -5.027 & -0.293 & -0.846 \\
\hline PEU2 & 3 & 5 & -0.832 & -4.806 & -0.316 & -0.914 \\
\hline PEU1 & 1 & 5 & -1.136 & -6.559 & 1.151 & 3.323 \\
\hline INF7 & 2 & 5 & -1.07 & -6.18 & 0.761 & 2.196 \\
\hline INF6 & 2 & 5 & -0.895 & -5.167 & 0.261 & 0.753 \\
\hline INF5 & 3 & 5 & -0.465 & -2.686 & -0.813 & -2.347 \\
\hline INF4 & 2 & 5 & -0.4 & -2.309 & -0.889 & -2.566 \\
\hline INF3 & 2 & 5 & -0.764 & -4.413 & -0.139 & -0.402 \\
\hline INF2 & 1 & 5 & -1.061 & -6.124 & 1.456 & 4.203 \\
\hline INF1 & 2 & 5 & -0.896 & -5.174 & 0.723 & 2.087 \\
\hline PUS7 & 2 & 5 & -0.838 & -4.839 & 0.045 & 0.129 \\
\hline PUS6 & 2 & 5 & -1.046 & -6.037 & 0.389 & 1.123 \\
\hline PUS5 & 2 & 5 & -0.44 & -2.543 & -0.659 & -1.903 \\
\hline PUS4 & 2 & 5 & -0.605 & -3.494 & -0.523 & -1.51 \\
\hline PUS3 & 1 & 5 & -1.385 & -7.997 & 2.044 & 5.901 \\
\hline PUS2 & 2 & 5 & -1.182 & -6.825 & 0.947 & 2.732 \\
\hline PUS1 & 2 & 5 & -1.399 & -8.079 & 1.957 & 5.65 \\
\hline HRG7 & 2 & 5 & -0.195 & -1.127 & -0.756 & -2.183 \\
\hline HRG6 & 1 & 5 & -0.069 & -0.401 & -0.395 & -1.141 \\
\hline HRG5 & 1 & 5 & -0.509 & -2.936 & -0.334 & -0.963 \\
\hline HRG4 & 2 & 5 & -1.268 & -7.321 & 1.032 & 2.979 \\
\hline
\end{tabular}


Lanjutan Tabel 4.

\begin{tabular}{lrrrrrr}
\hline Variable & min & \multicolumn{1}{c}{ max } & \multicolumn{1}{c}{ skew } & c.r. & kurtosis & \multicolumn{1}{c}{ c.r. } \\
\hline HRG3 & 2 & 5 & -0.433 & -2.501 & -0.313 & -0.904 \\
HRG2 & 1 & 5 & -0.617 & -3.562 & 0.435 & 1.255 \\
HRG1 & 1 & 5 & -0.59 & -3.408 & 0.019 & 0.054 \\
Multivariate & & & & & 328.097 & 39.07 \\
Sumber: Data primer yang diolah (2021) & & & &
\end{tabular}

Pengujian normalitas dilakukan untuk mengetahui nilai residual dapat terdistribusi secara normal atau tidak. Uji ini dilakukan dengan kriteria Critical Ratio Skewness Value (c.r. skew) yang berjumlah $\pm 2,58$ pada tingkat signifikansi 0,1 (10\%). Berdasarkan Tabel 4, dapat disimpulkan bahwa data bersifat normal secara univariate (c.r. skew) namun tidak normal secara multivariate karena hasil olah data menunjukan berjumlah lebih dari 2.58 .

Tabel 5.

Uji Goodness of Fit

\begin{tabular}{lllcc}
\hline No & \multicolumn{1}{c}{ Indeks } & \multicolumn{1}{c}{ Nilai Kritis } & Hasil & Keterangan \\
\hline 1 & Chi- Square & Semakin kecil nilainya maka model & 242.15 & Baik \\
2 & P-Value & $\geq 0,05$ & 0.098 & Baik \\
3 & X $^{2}$ DF & $\leq 2,00$ & 1.174 & Baik \\
4 & CFI & $\geq 0,95$ & 0.965 & Baik \\
5 & GFI & $\geq 0,90$ & 0.913 & Baik \\
6 & RMSEA & $\leq 0,08$ & 0.076 & Baik \\
7 & AGFI & $\geq 0,90$ & 0.928 & Baik \\
8 & TLI & $\geq 0,95$ & 0.952 & Baik \\
\hline
\end{tabular}

Sumber: Data primer yang diolah (2021)

Pengujian SEM memiliki syarat yang harus dipenuhi yang disebut Goodness of Fit (GOF). Uji GOF ini diartikan sebagai uji kecocokan model yang berarti pengujian hipotesis dalam menentukan suatu indikator frekuensi yang diekspektasikan dapat sama dengan frekuensi yang didapatkan dari suatu pendistribusian. Dari prinsip Rule of Thumb yang berbunyi apabila terdapat satu atau dua dari uji Goodness of Fit maka data dinyatakan baik atau terpenuhi (Latan \& Temalagi, 2013). Semakin rendah nilai RMSEA dari data yang telah diolah, maka semakin baik (Feinian et al. 2008; Hair et al. 2019). Berikut adalah tabel yang menyatakan langkah pengukuran kecocokan model. Berdasarkan uji kesesuaian model tersebut, diperoleh masing-masing nilai kritis terhadap model penelitian. Dari kedelapan uji kesesuaian model yang telah dilakukan seluruh uji dinyatakan baik sehingga dapat disimpulkan uji GOF dikategorikan baik. 


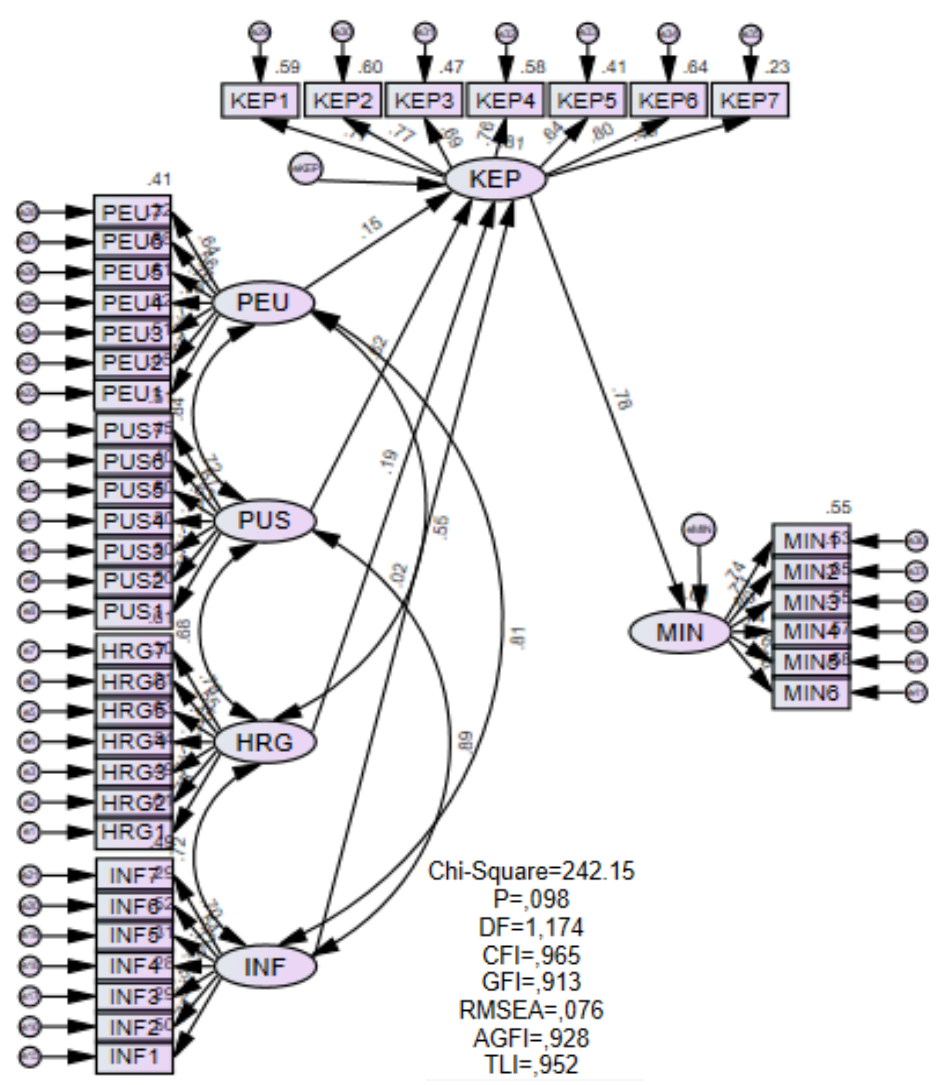

\section{Gambar 2. Analisis Model Struktural SEM}

Sumber: Data primer yang diolah (2021)

Setelah melakukan perhitungan variabel gabungan dan estimasi parameter, maka selanjutnya adalah menganalisis hubungan sebab-akibat dari konstruk gabungan dengan menggunakan model persamaan struktural. Model penelitian yang telah dikembangkan sebelumnya akan digunakan untuk mengukur model persamaan struktural pada langkah ini. Gambar 2 menunjukkan hasil model struktural dari ke-enam arahan yang dihipotesiskan. Dalam penelitian ini akan disimpulkan kelima hipotesis akan berpengaruh signifikan atau tidak.

Tabel 6.

Uji Hipotesis

\begin{tabular}{ccccc}
\hline Hipotesis & $\begin{array}{c}\text { Koefisien } \\
\text { Regresi }\end{array}$ & Standard Error & $\begin{array}{c}\text { Nilai } \\
\text { Signifikansi }\end{array}$ & Keterangan \\
\hline $\mathrm{PEU} \rightarrow$ KEP & 0.141 & 0.110 & 0.201 & $\begin{array}{c}\text { Tidak } \\
\text { signifikan } \\
\mathrm{PUS} \rightarrow \text { KEP }\end{array}$ \\
$\mathrm{HRG} \rightarrow$ KEP & 0.645 & 0.188 & 0.000 & Signifikan \\
Signifikan
\end{tabular}

Bersambung... 
Lanjutan Tabel 6.

\begin{tabular}{lcccc}
\hline Hipotesis & $\begin{array}{c}\text { Koefisien } \\
\text { Regresi }\end{array}$ & Standard Error & $\begin{array}{c}\text { Nilai } \\
\text { Signifikansi }\end{array}$ & Keterangan \\
\hline $\mathrm{INF} \rightarrow$ KEP & 0.022 & 0.178 & 0.902 & $\begin{array}{c}\text { Tidak } \\
\text { signifikan } \\
\text { KEP } \rightarrow \text { MIN }\end{array}$ \\
\hline Signifikan
\end{tabular}

Sumber: Data primer yang diolah (2021)

Pengujian hipotesis dalam penelitian ini bertujuan untuk melihat ada atau tidaknya hubungan antara variabel independen terhadap variabel laten. Kriteria dalam menentukan diterima atau tidaknya hipotesis yaitu nilai signifikansi atau $p$ value $<0,05$ untuk toleransi kesalahan a sebesar 5\% (Hitten \& Susanto, 2019).

Ditinjau dari hasil dari uji hipotesis yang telah dilaksanakan, dapat dinyatakan bahwa variabel Persepsi Keinformatifan tidak berpengaruh signifikan terhadap variabel Kepuasan Konsumen. Variabel Persepsi Harga berpengaruh signifikan terhadap variabel Kepuasan Konsumen. Variabel Perceived Usefulness berpengaruh signifikan terhadap Kepuasan Konsumen. Variabel Perceived Ease of Use tidak berpengaruh signifikan terhadap Kepuasan Konsumen. Variabel Kepuasan Konsumen berpengaruh signifikan terhadap Minat Beli Ulang.

Diketahui bahwa variabel Persepsi Keinformatifan berpengaruh positif terhadap variabel Kepuasan Konsumen dengan jumlah nilai koefisien regresi sebesar 0.022. Namun di sisi lain data menjelaskan bahwa dengan nilai signifikansi sebesar 0.902 maka $0.902>0.05$ sehingga dapat disimpulkan bahwa variabel Persepsi Keinformatifan tidak berpengaruh signifikan terhadap variabel Kepuasan Konsumen. Hasil penelitian ini bertolak belakang dengan penelitian Chandra \& Cassandra (2019) yang menunjukan bahwa Persepsi Keinformatifan berpengaruh signifikan terhadap Kepuasan Konsumen. Walaupun tidak signifikan, sebanyak $56 \%$ responden perempuan pengguna Go-Food tetap menyetujui bahwa kelengkapan informasi pada aplikasi memberikan rasa aman bagi konsumen (skor rata-rata 4.30). 38.64\% responden laki-laki menyatakan persetujuannya bahwa kelengkapan fitur informasi pada aplikasi Go-Food lebih baik (skor rata-rata 4.06). Dari hasil tersebut dapat dikatakan bahwa persepsi keinformatifan dapat meningkatkan pengetahuan serta memuaskan kebutuhan kognitif konsumen akan informasi produk atau layanan yang diberikan (Sigurdsson et al. 2018).

Hasil pada Tabel 6 menunjukan bahwa variabel Persepsi Harga berpengaruh positif terhadap variabel Kepuasan Konsumen dengan jumlah nilai koefisien regresi sebesar 0.132. Selain itu, terdapat nilai signifikansi sebesar 0.021 maka $0.021<$ 0.05. Dengan demikian dapat dinyatakan variabel Persepsi Harga berpengaruh signifikan terhadap variabel Kepuasan Konsumen. Hasil penelitian ini sejalan dengan penelitian Hitten \& Susanto (2019), Adinugraha \& H Michael (2014), dan Dwihapsari (2017) yang menyatakan bahwa Persepsi Harga memengaruhi Kepuasan Konsumen. Sebanyak 44\% responden laki-laki menyetujui bahwa harga produk yang dikeluarkan sesuai dengan manfaat yang didapatkan konsumen (skor rata-rata 4.09). Selain itu responden juga menyetujui bahwa harga jasa antar pada Go-Food sesuai dengan manfaat yang didapatkan konsumen (skor rata-rata 4.03). Namun Go-Food harus berhati-hati karena responden menyatakan dengan skor 
rata-rata 3.35 bahwa harga Go-Food tidak atau belum lebih terjangkau dari kompetitornya. Dengan ini, persepsi harga menjadi salah satu faktor penting yang cenderung sensitif dalam memengaruhi kepuasan konsumen (Saudina, 2020).

Dari perspektif variabel Perceived Usefulness, diketahui jumlah nilai koefisien regresi sebesar 0.645. Ini menjelaskan bahwa variabel Perceived Usefulness berpengaruh positif terhadap variabel Kepuasan Konsumen. Ini dibuktikan dengan nilai signifikansi sebesar 0.000 maka $0.000<0.05$ sehingga dapat dinyatakan variabel Perceived Usefulness berpengaruh signifikan terhadap variabel Kepuasan Konsumen. Hasil penelitian ini sejalan dengan penelitian Muflihhadi \& Rubiyanti (2016), Hitten \& Susanto (2019), Rukmiyati \& Budiartha (2016), dan Mandasari \& Giantari (2017) yang menyatakan bahwa Perceived Usefulness memengaruhi Kepuasan Konsumen. Ini terbukti bahwa responden mempercayai bahwa aplikasi Go-Food dapat memudahkan aktivitas konsumen (skor rata-rata 4.47). Persepsi kegunaan juga dapat memberikan rasa percaya kepada konsumen bahwa dengan menggunakan teknologi, maka seluruh kinerja akan meningkat (Wardhana, 2019). Pernyataan ini dibuktikan dengan responden menyetujui butir pertanyaan bahwa responden mempercayai sistem keamanan GoFood (skor rata-rata 4.22).

Melalui hasil Tabel 6, ditemukan jumlah nilai koefisien regresi sebesar 0.141. Berarti, variabel Perceived Usefulness berpengaruh positif terhadap variabel Kepuasan Konsumen. Melalui nilai signifikansi sebesar 0.201 maka $0.201>0.05$ sehingga dapat di tarik konklusi bahwa variabel Perceived Ease of Use tidak berpengaruh signifikan terhadap variabel Kepuasan Konsumen. Penelitian ini konsisten dengan penelitian Hitten \& Susanto (2019) yang menyatakan bahwa Perceived Ease of Use berpengaruh positif namun tidak signifikan terhadap Kepuasan Konsumen. Namun penelitian ini tidak konsisten dengan penelitian Mandasari \& Giantari (2017) yang menyatakan bahwa Perceived Ease of Use berpengaruh positif dan signifikan terhadap Kepuasan Konsumen. Mengunduh dan menggunakan Go-Food dapat menyediakan banyak manfaat untuk konsumen, namun belum seutuhnya membebaskan konsumen dari usaha, sehingga masih terdapat ketidakpuasan tersendiri (Hitten \& Susanto, 2019). Sebanyak 24 orang dari 200 responden menyebutkan bahwa konsumen sangat tidak puas dengan promo yang ditawarkan Go-Food dibanding aplikasi sejenis lainnya (skor rata-rata 3.84).

Pada variabel Kepuasan Konsumen, jumlah nilai koefisien regresi sebesar 0.817. Artinya, variabel Kepuasan Konsumen berpengaruh positif terhadap variabel Minat Pembelian Ulang. Selanjutnya, dengan nilai signifikansi sebesar 0.000 maka $0.000<0.05$ maka dapat dinyatakan variabel Kepuasan Konsumen berpengaruh signifikan terhadap variabel Minat Pembelian Ulang. Penelitian ini konsisten dengan penelitian G. F. C. Putri \& Novianti (2016), Hitten \& Susanto (2019), Puspitasari (2006), dan Ghassani \& Suryoko (2017) yang menyatakan bahwa Kepuasan Konsumen berpengaruh positif dan signifikan terhadap Minat Pembelian Ulang. Kepuasan Konsumen dapat diartikan sebagai perasaan konsumen yang muncul setelah melakukan perbandingan hasil kinerja produk yang dipikirkan terhadap hasil kinerja yang diharapkan (Roring et al. 2015). Sebanyak 56\% responden wanita menyetujui bahwa responden akan menggunakan aplikasi GoFood untuk jangka panjang (skor rata-rata 4.07). Selain itu, responden juga 
menyetujui bahwa responden akan merekomendasikan aplikasi Go-Food kepada keluarga, rekan, atau sahabat dengan nilai skor rata-rata 4.20.

\section{SIMPULAN}

Variabel Persepsi Keinformatifan tidak berpengaruh signifikan terhadap variabel Kepuasan Konsumen. Variabel Persepsi Harga berpengaruh positif dan signifikan terhadap variabel Kepuasan Konsumen. Variabel Perceived Usefulness berpengaruh positif dan signifikan terhadap variabel Kepuasan Konsumen. Variabel Perceived Ease of Use tidak berpengaruh signifikan terhadap variabel Kepuasan Konsumen. Variabel Kepuasan Konsumen berpengaruh signifikan terhadap variabel Minat Pembelian Ulang. Berdasarkan hasil dan analisa dalam penelitian ini, diketahui bahwa apabila dirata-rata keseluruhan konsumen Go-Food sebagai responden memberikan nilai data yang baik dengan total skor rata-rata 4.21.

Guna dapat meningkatkan pembelian ulang Go-Food, peneliti memberikan beberapa saran sebagai berikut: Konsumen Go-Food mengeluhkan sedikitnya promo berupa voucher dan harga layanan yang lebih tinggi dari kompetitor, shareholders harus mempertimbangkan hal ini untuk dapat menambah kuantitas konsumen karena harga sangat bersifat sensitif. Pihak software development diharapkan dapat memperbaiki tingkat akurasi informasi beserta akurasi map agar konsumen mengetahui detail letak pesanan dengan benar karena beberapa responden mengeluhkan konfigurasi map yang salah dan tidak akurat. Internal perusahaan harus memikirkan strategi untuk mendapatkan profit dari sektor lain sehingga dapat memangkas tarif dan dapat meminimalisir resiko kerugian.

\section{REFERENSI}

Adinugraha, A. T., \& H Michael, S. (2014). Analisa Pengaruh Kualitas Makanan dan Persepsi Harga Terhadap Kepuasan Konsumen D'cost Surabaya. Hospitality Dan Manajemen Jasa, 3, 643-655.

Aditya, R., \& Wardhana, A. (2016). Pengaruh perceived usefulness dan perceived ease of use terhadap behavioral intention dengan pendekatan Technology Acceptance Model (TAM) pada pengguna Instant Messaging LINE di Indonesia. Jurnal Siasat Bisnis, 20(1), 24-32. https://doi.org/10.20885/jsb.vol20.iss1.art3

Amita, N. L. (2015). Pengaruh Persepsi Kegunaan, Persepsi Kemudahan, Persepsi Risiko Terhadap Minat Menggunakan Layanan Produk BRILink (Studi pada Masyarakat di Kota Kediri). 3(2), 54-67. Retrieved from http://repositorio.unan.edu.ni/2986/1/5624.pdf

Andhini, A. (2017). Pengaruh Transaksi Online Shopping, dan Kepercayaan Konsumen terhadap Kepuasan Konsumen pada E-Commerce. Jurnal Ilmu Dan Riset Manajemen, 6(7), 1-23. Retrieved from http://jurnalmahasiswa.stiesia.ac.id/index.php/jirm/article/download/1753/17 63 
Anggraeni, R. (2015). Pengaruh Persepsi Kemudahan Penggunaan Dan Persepsi Kegunaan Terhadap Niat Untuk Menggunakan Dan Penggunaan Aktual Layanan Jejaring Sosial Berbasis Lokasi (Studi Pada Mahasiswa Fakultas Ekonomi Dan Bisnis Universitas Brawijaya Malang). Ekonomi Bisnis, 20(1), 44-52. https://doi.org/10.17977/um042v20i1p44-52

APJII. (2019). Penetrasi \& Profil Perilaku Pengguna Internet Indonesia Tahun 2018. Apjii, 51. Retrieved from www.apjii.or.id

Aristo, S. F. (2016). Pengaruh produk, harga, dan promosi terhadap keputusan pembelian konsumen woles chips. Jurnal Manajemen Dan Start-Up Bisnis, 1(4), 441-447.

Arnindita Palma, M. \&, \& Lestari Andjarwati, A. (2016). Pengaruh Kualitas Produk , Kemudahan dan Harga Terhadap Niat Beli Ulang Dengan Kepuasan Sebagai Variabel Intervening ( Studi Pada Pelanggan Produk Fashion Melalui Toko online di Surabaya ). Jurnal Riset Ekonomi Dan Manajemen, 16(1), 84-104.

Ayuningrum, S. (2016). Pengaruh Kemudahan Penggunaan PEngalaman Sebelumnya, Kepercayaan Konsumen, dan Persepsi Harga Terhadap Minat Beli Dalam Transaksi Belanja Online.

Babu, J., Sophia, J., \& Dave, J. X. (2020). Consumer Perception Towards Online Food Ordering and Delivery Services with Special Reference to Zomato, Swiggy and Uber Eats. (170021063433).

BPS. (2020). Distribusi PDRB Jawa Tengah Atas Dasar Harga Berlaku Menurut Pengeluaran.

Brenda L Curtis, Ashford, R. D., Magnuson, K. I., \& Ryan-Pettes, S. R. (2019). Comparison of Smartphone Ownership, Social Media Use, and Willingness to Use Digital Interventions Between Generation $\mathrm{Z}$ and Millennials in the Treatment of Substance Use: Cross-Sectional Questionnaire Study. J Med Internet Res, 21. https://doi.org/10.2196/13050

Byrne, B. M. (1998). Structural equation modeling with LISREL, PRELIS, and SIMPLIS: Basic concepts, applications, and programming. Retrieved from https://psycnet.apa.org/record/1998-07491-000

Chandra, Y. U., \& Cassandra, C. (2019). Stimulus Factors of Order Online Food Delivery. Proceedings of 2019 International Conference on Information Management and Technology, ICIMTech 2019, 1, 330-333. https://doi.org/10.1109/ICIMTech.2019.8843715

Chen, L. W. (2019). Impact Assessment of Food Delivery on Urban Traffic. Proceedings - IEEE International Conference on Service Operations and 
Logistics, and Informatics 2019, SOLI 2019, 236-241. https://doi.org/10.1109/SOLI48380.2019.8955108

Dwihapsari, B. C. (2017). Analisis Pengaruh Kualitas Pelayanan dan Persepsi Harga Terhadap Kepuasan Konsumen dalam Menggunakan Jasa Pada Oryza Tour.

Faradisa, I., Budi, L., \& Minarsih, M. M. (2016). Analisis Pengaruh Variasi Produk, Fasilitas, dan Kualitas Pelayanan terhadap Minat Beli Ulang Konsumen pada Indonesian Coffeeshop Semarang (ICOS CAFE). Journal of Management, 02(02), 1-13.

Feinian, C., Curran, P. J., Bollen, K. A., Kirby, J., \& Paxton, P. (2008). An empirical evaluation of the use of fixed cutoff points in RMSEA test statistic in structural equation models. Sociological Methods and Research, 36(4), 462-494. https://doi.org/10.1177/0049124108314720

Firmanto, Y., \& Rozi, A. F. (2018). Analisis faktor-faktor yang mempengaruhi kepuasan pengguna software akuntansi dan dampaknya terhadap kinerja individu. Jurnal Ilmiah Mahasiswa Manajemen.

Ghassani, M. T., \& Suryoko, S. (2017). Pengaruh Kualitas Produk dan Harga Terhadap Minat Beli Ulang Bandeng Juwana Vaccum Melalui Kepuasan Konsumen Sebagai Variabel Intervening (Studi Kasus Pada Pelanggan PT. Bandeng Juwana Elrina Semarang).

Ghozali, I. (2017). Model Persamaan Struktural. Konsep dan Aplikasi Dengan Program AMOS 24.0. Update Bayesian SEM. In Model Persamaan Struktural. Konsep dan Aplikasi Dengan Program AMOS 24. Update Bayesian SEM. https://doi.org/10.1016/j.ando.2009.02.007

Hair, J. F., Ringle, C. M., Gudergan, S. P., Fischer, A., Nitzl, C., \& Menictas, C. (2019). Partial least squares structural equation modeling-based discrete choice modeling: an illustration in modeling retailer choice. Business Research, 12(1), 115-142. https://doi.org/10.1007/s40685-018-0072-4

Hamid, A. A., Razak, F. Z. A., Bakar, A. A., \& Abdullah, W. S. W. (2016). The Effects of Perceived Usefulness and Perceived Ease of Use on Continuance Intention to Use E-Government. Procedia Economics and Finance, 35(October 2015), 644-649. https://doi.org/10.1016/s2212-5671(16)00079-4

Hanggono, A. (2015). Analisis Atas Praktek Tam (Technology Acceptance Model) Dalam Mendukung Bisnis Online Dengan Memanfaatkan Jejaring Sosial Instagram. Jurnal Administrasi Bisnis S1 Universitas Brawijaya, 26(1), 86245. 
Harjati, L., \& Venesia, Y. (2015). Pengaruh Kualitas Layanan dan Persepsi Harga Terhadap Kepuasan Pelanggan Pada Maskapai Penerbangan Tiger Air Mandala. E-Journal WIDYA Ekonomika, 1(2015), 64-74.

Hastuti, R. K. (2019). Gojek Telah Diunduh 142 Juta Kali. Retrieved from https://www.cnbcindonesia.com/tech/20190423171542-37-68367/gojektelah-diunduh-142-juta-kali

Hendraningtiyas, Y. A. L., \& Soediono, W. (2015). Pengaruh Site Design, Informativeness, Dan Security Terhadap Custamer Satisfaction Online Web Retailing Zalora Indonesia. Jurnal Bianis Dan Akuntansi, 17(2), 190-196.

Hidayatullah, S., Waris, A., \& Devianti, R. C. (2018). Perilaku Generasi Milenial dalam Menggunakan Aplikasi Go-Food. Jurnal Manajemen Dan Kewirausahaan, 6(2), 240-249. https://doi.org/10.26905/jmdk.v6i2.2560

Hitten, A., \& Susanto, A. (2019). Faktor-Faktor yang Mempengaruhi Kepuasan Karyawan Kantoran Serta Dampaknya pada Niat untuk Menggunakan Ulang Layanan Aplikasi Go- Food di Pontianak. Jurnal Ekonomi Bisnis Dan Kewirausahaan, 8(2), 94. https://doi.org/10.26418/jebik.v8i2.26851

Imam Heryanto. (2015). Analisis pengaruh produk, harga, distribusi, dan promosi terhadap keputusan pembelian serta implikasinya pada kepuasan pelanggan. Jurnal Ekonomi, Bisnis \& Entrepreneurship, 9(2), 80-101. https://doi.org/2443-2121Heryanto, I. (2015). Analisis pengaruh produk, harga, distribusi, dan promosi terhadap keputusan pembelian serta implikasinya pada kepuasan pelanggan. Ekonomi, Bisnis \& Entrepreneurship, 9(2), 80-101. http://doi.org/2443-2121

Indraswari, A., \& Kusuma, H. (2018). Analisa Pemanfaatan Aplikasi Go-Food Bagi Pendapatan Pemilik Usaha Rumah Makan Di Kelurahan Sawojajar Kota Malang. Jurnal Ilmu Ekonomi, 2, 63-73. Retrieved from http://ejournal.umm.ac.id/index.php/jie/article/view/6967

Kartika, A. (2017). Pengaruh Persepsi Kegunaan, Persepsi Kemudahan, dan Persepsi Keamanan Terhadap Minat Penggunaan BRI Mobile. 1-18.

Kartika, E. K. (2014). Pengaruh Bauran Pemasaran Terhadap Niat Beli Ulang Sepeda Motor Honda Kategori Sport Mid. E-Journal Graduate Unpar, 1(2), 141-149.

Kucukusta, D., Law, R., Besbes, A., \& Legohérel, P. (2015). Re-examining perceived usefulness and ease of use in online booking: The case of Hong Kong online users. International Journal of Contemporary Hospitality Management, (Unit 07), 1-5. 
Latan, H., \& Temalagi, S. (2013). Analisis Multivariate: Teknik dan Aplikasi Menggunakan Program IBM SPSS 20.0. Retrieved from https://openlibrary.telkomuniversity.ac.id/pustaka/98931/analisismultivariate-teknik-dan-aplikasi-menggunakan-program-ibm-spss-20-0.html

Liang, L. J., Choi, H. C., \& Joppe, M. (2018). Understanding repurchase intention of Airbnb consumers: perceived authenticity, electronic word-of-mouth, and price sensitivity. Journal of Travel and Tourism Marketing, 35(1), 73-89. https://doi.org/10.1080/10548408.2016.1224750

Malik, F., Yaqoob, S., \& Aslam, A. S. (2012). The Impact of Price Perception, Service Quality, and Brand Image on Customer Loyalty (Study of Hospitality Industry in Pakistan). Interdisciplinary Journal of Contemporary Research in Business, 4(5), 487-506.

Mandasari, C. S., \& Giantari, I. G. A. K. (2017). Pengaruh Perceived Usefulness, Perceived Ease of Use, dan Kualitas Layanan Terhadap Kepuasan Untuk Membangun Loyalitas. E-Jurnal Ekonomi Dan Bisnis Universitas Udayana. https://doi.org/10.24843/eeb.2017.v06.i10.p08

Muflihhadi, I., \& Rubiyanti, R. N. (2016). Pengaruh Perceived Usefulness , Perceived Ease of Use, Dan Trust Terhadap Kepuasan Konsumen ( Studi Pada Gojek Bandung ) the Impact of Perceived Usefulness, Perceived Ease of Use , and Trust in Custome Rs' Satisfaction ( Case Study in Gojek Bandung ). EProceeding of Management, 3(2), 2026-2033.

Muslimin, M. (2012). Perkembangan Teknologi Dalam Industri Media. Jurnal Teknik Industri, 12(1), 57. https://doi.org/10.22219/jtiumm.vol12.no1.57-64

Nasution, L. M. (2017). Statistik Deskriptif. Jurnal Hikmah, 77(21), 5472-5476. https://doi.org/10.1021/ja01626a006

Natalia, K., Ompusunggu, A. P., \& Sarwono, J. (2019). Pengaruh Persepsi Kegunaan Dan Persepsi Kemudahan Terhadap Penggunaan E-Filing Dan Dampaknya Terhadap Kepatuhan Wajib Pajak Orang Pribadi Pada Kpp Pratama Gambir Tiga (Survei Pada Kpp Pratama Gambir Tiga Periode AprilJuli 2017). Jurnal Muara Ilmu Ekonomi Dan Bisnis, 3(1), 186. https://doi.org/10.24912/jmieb.v3i1.1922

Nur, A. (2019). Faktor-Faktor yang Memengaruhi Perilaku Generasi Milenial dalam Penggunaan Go-Food di Kota Makassar.

Pardede, R., \& Haryadi, T. Y. (2017). Pengaruh Persepsi Harga Dan Kualitas Produk Terhadap Keputusan Pembelian Konsumen Yang Dimediasi Kepuasan Konsumen. Journal of Business \& Applied Management, 10(1). https://doi.org/10.30813/jbam.v10i1.870 
Puspitasari, D. (2006). nalisis Pengaruh Persepsi Kualitas Dan Kepuasan Pelanggan Terhadap Minat Beli Ulang (Studi Kasus pada Maskapai Penerbangan Garuda Keberangkatan Semarang). Retrieved from http://eprints.undip.ac.id/9698/

Putri, G. F. C., \& Novianti, N. (2016). Pengaruh Persepsi Kegunaan, Persepsi Kemudahan, Kenyamanan, Kepercayaan, Kepuasan, dan Loyalitas Pelanggan Terhadap Minat Pembelian Kembali Secara Online.

Putri, P. K. (2016). Aplikasi Pendekatan-Pendekatan Persuasif Pada Riset Komunikasi Pemasaran: Iklan Melibatkan Penciptaan dan Penerimaan Pesan Komunikasi Persuasif Mengubah Perilaku Pembelian. E-Jurnal Akuntansi, 15(2), 1-23. https://doi.org/.1037//0033-2909.I26.1.78

Rahman, D. N. (2013). Pada Pemancingan Ngrembel Asri Gunungpati Semarang.

Ramadhon, M. F., \& Fardiyan, A. R. (2016). Simbol-Simbol Pesan Persuasif Melalui Design Poster Event Musik NgayogJazz Festival. 2(1), 23-36.

Rizky Iryanita, Y. S. (2013). Analisis Pengaruh Citra Merek, Persepsi Harga, dan Persepsi Kualitas Produk Terhadap Keputusan Pembelian (Studi Pada Konsumen produk ATBM Pekalongan) Rizky Iryanita, Y. Sugiarto 1. Dpponegoro Journal of Management, 2, 1-9. Retrieved from http://eprints.undip.ac.id/68440/

Roring, F., Oroh, S., \& Gulla, R. (2015). Analisis Harga, Promosi, Dan Kualitas Pelayanan Terhadap Kepuasan Konsumen Pada Hotel Manado Grace Inn. Jurnal Riset Ekonomi, Manajemen, Bisnis Dan Akuntansi, 3(1), 1313-1322.

Ruiz-Mafe, C., Chatzipanagiotou, K., \& Curras-Perez, R. (2018). The role of emotions and conflicting online reviews on consumers' purchase intentions. Journal of Business Research, 89(January), 336-344. https://doi.org/10.1016/j.jbusres.2018.01.027

Rukmiyati, N. M. S., \& Budiartha, I. K. (2016). Pengaruh Kualitas Sistem Informasi, Kualitas Informasi, Dan Perceived Usefulness Terhadap Kepuasan Pengguna Akhir Software Akuntansi (Studi Empiris Pada Hotel Berbintang Di Provinsi Bali). E-Jurnal Ekonomi Dan Bisnis Universitas Udayana.

Saudina, M. (2020). Analisis Faktor-Faktor Yang Mempengaruhi Perilaku Mahasiswa dalam menggunakan Go-Food di Kota Jambi. 14(1), 1-13.

Savitri, I. A. P. D., \& Wardana, I. M. (2018). Pengaruh Citra Merek, Kualitas Produk Dan Persepsi Harga Terhadap Kepuasan Dan Niat Beli Ulang. EJurnal Manajemen Universitas Udayana, 7(10), 5748. 
https://doi.org/10.24843/ejmunud.2018.v07.i10.p19

Sepang, J., \& Joel, G. (2014). Pengaruh Motivasi, Persepsi Harga, Dan Kualitas Produk Terhadap Minat Beli Konsumen Sepeda Motor Matic Merek Yamaha Mio Di Kota Manado. Jurnal Riset Ekonomi, Manajemen, Bisnis Dan Akuntansi, 2(3), 1463-1472. https://doi.org/10.35794/emba.v2i3.5895

Setiarsih, H. (2017). Analisis Pengaruh Citra Merek dan Persepsi Kualitas Terhadap Keputusan Pembelian Go Food (studi pada Mahasiswa STIE Widya Wiwaha Yogyakarta).

Setyo, P. E. (2017). Pengaruh Kualitas Produk Dan Harga Terhadap Kepuasan Konsumen "Best Autoworks." PERFORMA: Jurnal Manajemen Dan StartUp Bisnis, 1, 755-764.

Sidharta, I., \& Boy Suzanto. (2015). Pengaruh Kepuasan Transaksi Online Shopping Dan Kepercayaan Konsumen Terhadap Sikap Serta Perilaku Konsumen Pada E-Commerce. Jurnal Computech \& Bisnis, 9(1), 23-36. Retrieved from http://jurnal.stmikmi.ac.id/index.php/jcb/article/download/124/148

Sigurdsson, V., Menon, R. G. V., Hallgrímsson, A. G., Larsen, N. M., \& Fagerstrøm, A. (2018). Factors Affecting Attitudes and Behavioral Intentions Toward In-app Mobile Advertisements. Journal of Promotion Management, 24(5), 694-714. https://doi.org/10.1080/10496491.2018.1405523

Soliha, E. (2019). Pengaruh Persepsi Harga, Citra Perusahaan dan Citra Merek Terhadap Kepuasan dan Loyalitas Pelanggan Pada Apotek "Dela" di Semarang.

Sumaedi, S., Bakti, I., \& Metasari, N. (2011). The effect of students' perceived service quality and perceived price on student satisfaction. Management Science and ..., 5(1), 88-97. Retrieved from http://www.cscanada.net/index.php/mse/article/view/1373

Swastha, B. (2016). Pengaruh Kualitas Produk Dan Harga Terhadap Keputusan Pembelian Produk Kosmetik Wardah Di Kota Bangkalan Madura. Jurnal Ekonomi , Bisnis \& Entrepreneurship, 1(1), 31-48.

Syaninditha, S. A. P., \& Setiawan, P. E. (2017). Pengaruh Persepsi Kegunaan, Persepsi Kemudahan, Faktor Sosial, Dan Kondisi Yang Memfasilitasi Terhadap Minat Penggunaan E-Filing. E-Jurnal Akuntansi, 21, 86-115.

Ta'arufi, U., \& Yamit, Z. (2017). Pengaruh Kualitas Sistem, Informasi, Pelayanan Rail Ticketing System (RTS) Terhadap Kepuasan dan Loyalitas Pelanggan PT. Kereta Api Indonesia DAOP 6 Yogyakarta. Journal of Chemical 
Information and Modeling, 53(9), 1689-1699. https://doi.org/10.1017/CBO9781107415324.004

Umamah, faroh fahriyatul, \& Pribadi, joni dwi. (2006). Kegunaan Terhadap Sikap Perilaku Penggunaan Aplikasi. Jurnal Aplikasi Bisnis, 17-20.

Wardhana, O. H. P. (2019). Pengaruh Persepsi Kemudahan, Persepsi Kegunaan, Persepsi Nilai, Pengaruh Sosial, Persepsi Risiko, dan Kepercayaan Terhadap Minat Menggunakan E-commerce. Journal of Chemical Information and Modeling, 53(9), 1689-1699. https://doi.org/10.1017/CBO9781107415324.004

Wardoyo, S. (2013). Pt . Jasa Marga ( Persero ) Tbk, Cabang Semarang. 28(2), $55-63$.

Webster, J., Harrison, S., \& Morris, J. (2018). Communicative informativeness in aphasia. Aphasiology, 32(sup1), 243-245. https://doi.org/10.1080/02687038.2018.1485840

Widodo, A., \& Putri, A. S. A. (2017). Pengaruh Persepsi Kegunaan Dan Persepsi Kemudahan Penggunaan Terhadap Sikap Penggunaan Teknologi Pada Pengguna Instagram Di Indonesia (Studi Pada Followers Akun Kementerian Pariwisata@Indtravel).Journal of Secretary and Business Administration, 1(1), 18. https://doi.org/10.31104/jsab.v1i1.8

Wijaya, C. V. (2017). Pengaruh Harga, Kualitas Pelayanan Dan Kualitas Produk Terhadap Kepuasan Konsumen Depot Madiun Masakan Khas Bu Rudy. Agora, 5(1), 1-8.

Wijaya, W. (2017). Analisa Pengaruh Kualitas Makanan Terhadap Kepuasan Konsumen di Yoshinoya Galaxy Mall Surabaya. Hospitality Dan Manajemen Jasa, 5(2002), 581-594. Retrieved from http://publication.petra.ac.id/index.php/manajemenperhotelan/article/view/6198/5698

Wingsati, W. E., \& Prihandono, D. (2017). Pengaruh Penanganan Kegagalan Layanan, Kepercayaan, Dan Gaya Hidup Terhadap Minat Pembelian Ulang Melalui Kepuasan Konsumen. Management Analysis Journal, 6(2), 1-11. https://doi.org/10.15294/maj.v4i2.10272

Yonathan, I. C. (2013). Pengaruh Kompetensi, Informasi, Karyawan dan Bukti Fisik Terhadap Kepuasan dan Loyalitas Konsumen Pada Zangrandi Di Surabaya. Jurnal Hospitality Dan Manajemen Jasa, 1(No 2). 